\title{
PEMBENTUKAN KARAKTER UNGGUL DAN NASIONALIS PADA ANAK USIA DINI MELALUI SEKAR RARE
}

\author{
Oleh \\ Si Luh Nyoman Seriadi \\ Dosen IHDN Denpasar \\ nyomanseriadi@gmail.com
}

\begin{abstract}
Characther Building must be started in early age. Hence, the earlier children being acquinted with noble value, then their basic charater would be stronger in the future. Furthermore, to build such a noble character towards the children itself, their environment should reflect good and positive things vise versa. One of the methods to build their character is through introducing song for children with positive values as well as moral messages. Moral values inserted in the lyrics of children's songs are intended to educate the development of a child's psychology. The dolanan song or commonly known as Gending rare in Balinese culture provide such positive benefit in order to build character. Whereas, Gending Rare comprise educational values such as honesty, concord, history, culture, nationalism, and respect other peole, including another several positive things. The example of Gending Rare which will be explained in this papper is gending rare entitle "mare bangun" and "merah putih".
\end{abstract}

\section{Keywords: Characther Building, Early Childhood, Sekar Rare}

\begin{abstract}
Abstrak
Pembentukan SDM dimulai sejak usia dini. Semakin dini anak mengenal nilai-nilai baik maka semakin kuat fondasi karakternya dimasa yang akan datang. Untuk membentuk karakter mulia pada diri anak maka segala sesuatu disekitar anak harus mulia dan positif. Salah satu cara untuk membentuk karakter anak-anak adalah dengan cara memperkenalkan lagu anak-anak yang bermuatan nilai-nilai positif dan pesan moral di dalamnya. Nilai moral yang disisipkan dalam lirik lagu anak-anak ini dimaksudkan untuk mendidik perkembangan psikologi seorang anak. Lagu dolanan anak atau yang dalam budaya Bali dikenal dengan gending rare memiliki manfaat yang positif di dalam pembentukan karakter karena, mengandung nilainilai kependidikan di antaranya nilai kejujuran, kerukunan, sejarah, budaya, nasionalisme dan menghormati orang lain dan masih banyak hal positif lainnya lagi. Contoh Gending Rare yang dijelaskan dalam tulisan ini adalah gending rare berjudul "mara bangun" dan "merah putih".
\end{abstract}

\section{Kata Kunci:Pembentukkan Karakter, Anak Usia Dini, Sekar Rare}

\section{PENDAHULUAN}

Pendidikan beberapa tahun terakhir tidak hanya mengutamakan nilai secara akademis (kognitif) namun juga ranah afektif. Negara terdesak untuk menghasilkan generasi yang memiliki karakter mulia. Hal ini disebabkan karena salah satu kunci keberhasilan bangsa terletak pada kualitas sumber daya manusia. Pembentukan SDM dimulai sejak usia dini. Semakin dini anak mengenal nilai-nilai baik maka semakin kuat fondasi karakternya dimasa yang akan datang. Untuk membentuk karakter 
mulia pada diri anak maka segala sesuatu disekitar anak harus mulia dan positif. Dengan demikian, penerapan nilai-nilai moral yang baik membentuk karakter anak sebaiknya dikenalkan sejak usia dini dan melibatkan lingkungan.

Freud (Santrock \& Yussen, 1992; Solehuddin, 2000) memandang usia lima tahun pertama pada masa kanakkanak sebagai masa terbentuknya kepribadian dasar individu. Kepribadian orang dewasa ditentukan oleh cara-cara pemecahan konflik antara sumber-sumber kesenangan awal dengan tuntutan realita pada masa kanak-kanak. Pada masa usia ini penuh dengan kejadian-kejadian yang penting dan unik, yang meletakkan dasar bagi kehidupan seseorang di masa dewasa. Berkaitan dengan itu, tujuan pendidikan kanak-kanak adalah untuk memfasilitasi pertumbuhan dan perkembangan anak secara optimal dan menyeluruh, sesuai dengan norma-norma dan nilai-nilai kehidupan yang dianut. Melalui pendidikan ini diharapkan anak dapat mengembangkan segenap potensi yang dimilikinya, yang mencakup aspek agama, intelektual, sosial, ekonomi, dan fisik, memiliki dasar-dasar akidah yang lurus/benar sesuai dengan ajaran agama yang dianutnya, memiliki kebiasaankebiasaan perilaku yang diharapkan, menguasai sejumlah pengetahuan dan ketrampilan dasar sesuai dengan kebutuhan dan tingkat perkembangannya, serta memiliki motivasi dan sikap bahasa yang selaras dengan perkembangan jaman.

Salah satu cara untuk membentuk karakter anak-anak adalah dengan cara memperkenalkan lagu anak-anak yang bermuatan nilai-nilai positif dan pesan moral di dalamnya. Nilai moral yang disisipkan dalam lirik lagu anakanak ini dimaksudkan untuk mendidik perkembangan psikologi seorang anak. Menurut penelitian yang telah dikembangkan, mendidik seorang anak melalui lagu akan lebih efektif karena melalui musik akan lebih mudah diinterpretasi oleh otak anak serta akan cenderung bertahan lebih lama dalam ingatannya. Anak-anak akan lebih mudah belajar mengenal benda, bentuk, warna, binatang, membaca, berhitung dan berbagai pengetahuan tentang dunia luar melalui lagu.

Lagu anak-anak saat ini makin kehilangan identitasnya, bahkan anakanak sekarang lebih cepat menghafal lirik lagu-lagu remaja dan dewasa dibanding lirik lagu anak-anak. Padahal lirik lagu remaja dan dewasa banyak yang tidak layak dinyanyikan oleh anak-anak. Maka dari itu pemilihan lagu untuk anak-anak sangatlah penting.

Lagu dolanan anak atau yang dalam budaya Bali dikenal dengan gending rare memiliki manfaat yang positif di dalam pembentukan karakter karena, mengandung nilai-nilai kependidikan di antaranya nilai kejujuran, kerukunan, sejarah, budaya, nasionalisme dan menghormati orang lain dan masih banyak hal positif lainnya lagi. Tidak hanya dari segi pendidikan, dari segi kesehatan ternyata permainan dalam dolanan anak seperti gending rare di Bali memiliki manfaat untuk pembentukan fisik anak melalui gerakan-gerakan 
dalam permainan. Selain itu, kreativitas anak juga terbentuk dalam setiap teknik permainan yang dilakukannya. Contoh Gending Rare yang dijelaskan dalam tulisan ini adalah gending rare berjudul "mara bangun" dan "merah putih".

\section{PEMBAHASAN}

Menurut Undang Undang Nomer 20 Tahun 2003 tentang Sistem Pendidikan Nasional Pasal 3, Pendidikan Nasional berfungsi mengembangkan kemampuan dan membentuk karakter serta peradaban bangsa yang bermartabat dalam rangka mencerdaskan kehidupan bangsa. Pendidikan Nasional juga bertujuan untuk berkembangnya potensi peserta didik agar menjadi manusia yang beriman dan bertakwa kepada Tuhan Yang Maha Esa, berakhlak mulia, sehat, berilmu, cakap, kreatif, mandiri dan menjadi warga negara yang demokratis serta bertanggung jawab.

Pendidikan karakter sendiri adalah proses pendidikan yang ditujukan untuk mengembangkan nilai, sikap, dan perilaku yang memancarkan akhlak mulia atau budi pekerti luhur. Sehingga Pendidikan karakter di nilai sangat penting untuk di tanamkan dalam diri anak-anak sejak usia dini. Melalui pendidikan karakter ini anak usia dini disiapkan untuk meningkatkan mutu penyelenggaraan dan hasil pendidikan di sekolah yang mengarah pada pencapaian pembentukan karakter dan akhlak mulia peserta didik secara utuh, terpadu, seimbang, dan sesuai dengan standar kompetensi lulusan.
Menurut Thomas Lickona (via Megawangi, 2004) pendidikan karakter terdiri dari 3 bagian yang saling terkait. Karakter yang baik terdiri dari mengetahui kebaikan (knowing the good), mencintai atau menginginkan kebaikan (loving or dering the good), dan melakukan kebaikan (acting the good) oleh karena itu, cara membentuk karakter yang efektif adalah dengan melibatkan ketiga aspek tersebut. Ratna Megawangi menjelaskan bahwa dalam pendidikan karakter ada tiga hal yang harus ditekankan.

Pertama, knowing the good. Dalam membentuk karakter, anak tidak hanya sekedar tahu mengenai hal-hal yang baik, akan tetapi mereka harus dapat memahami apa makna dari perbuatan baik itu (mengapa seseorang perlu melakukan hal tersebut). Dalam konteks ini lebih ditekankan agar anak mengerti akan kebaikan dan keburukan, mengerti tentang tindakan apa yang harus diambil serta mampu memberikan prioritas halhal yang baik.

Kedua, feeling the good. Konsep ini lebih menekankan bagaimana membangkitkan rasa cinta anak untuk melakukan perbuatan baik. Anak dilatih untuk merasakan efek dari perbuatan yang baik yang dilakukan. Anak mempunyai kecintaan terhadap kebajikan dan membenci perbuatan buruk.

Ketiga, acting the good. Pada aspek ini, anak dilatih untuk melakukan perbuatan baik. Tanpa melakukan apa yang sudah diketahui atau dirasakan oleh seseorang, tidak akan ada artinya anak harus mampu melakukan kebajikan dan dapat terbiasa melakukannya. Melakukan 
kebaikan tidak hanya menjadi sebatas pengetahuan, namun dapat diwujudkan menjadi tindakan nyata.

Dalam upaya Pendidikan karakter pada anak-anak usia dini, ada banyak metide yang bisa dilakukan. Seperti halnya melaluli musik, nyanyian, suara, gerakan, bicara, perabaan, membaca, mencocokkan, membandingkan, mengelompokkan, memecahkan masalah, mencoret, merangkai, maupun menggambar. Salah satu cara yang dapat kita lakukan dalam mengenalkan pendidikan karakter pada anak-anak adalah melalui Musik dan lagu. Dengan nada-nada dan kalimat yang sederhana kita dapat mendidik moral anak.

Menurut Nurita (2011), lagu anak mengajarkan suatu budi pekerti yang memberikan pengaruh baik dalam pertumbuhan mereka. Dengan kata lain, dampak positif dalam lagu anak yang mengajarkan tentang suatu tindakan sopan santun dapat mempengaruhi pikiran, jiwa dan raga mereka sebab lagu anak yang tepat dapat mencakup semua aspek tujuan pembelajaran pada anak. Beberapa aspek tujuan pembelajaran yang terdapat pada lagu anak yang mengajarkan budi pekerti adalah:

1. Aspek kognitif atau pemahaman dan pemikiran mereka terhadap pengetahuan tentang tingkah laku terpuji.

2. Aspek afektif yang menekankan pada pengaruh lagu anak terhadap emosi atau perasaan serta prilaku mereka.

3. Aspek psikomotorik yakni kemampuan mereka dalam berprilaku sopan santun, yang tercermin dalam keterampilan berkomunikasi verbal atau non verbal sesuai dengan keadaan dan situasi.

Manfaat lain dari musik menurut Timothy Wibowo (2013) adalah:

1. Musik menstimulasi bagian otak anak yang berhubungan dengan membaca, matematika, dan juga perkembangan emosional anak. Anak akan lebih cepat menghafal huruf a,b,c atau angka melalui musik anakanak daripada menyuruh menghafalkan secara langsung.

2. Musik melatih ingatan anak. Belajar lagu atau musik sesuatu yang menyenangkan untuk anak-anak, ingatan tentang lirik lagu atau nada musik cepat dihafalkan oleh anakanak. Dengan musik, ingatan anak terbiasa atau terasah dengan baik melalui cara yang menyenangkan untuknya

3. Musik membantu perkembangan anak dalam hal sosial. Menikmati musik bersama-sama dengan temanteman yang lainnya menjadi saat yang menyenangkan. Permainan musik kecil bareng sekeluarga di saat-saat santai, membuat si kecil belajar bekerja sama dalam satu team, belajar bersosialisasi serta mengembangkan kemampuannya mengikuti aturanaturan kecil di dalam permainan musik.

4. Musik melatih anak mengekspresikan perasaan dan empati anak. Melodi yang bahagia 
membuat si kecil menari-nari dengan senang, melodi lembut menenangkan si kecil, melodi yang menghentak bisa membuat si kecil takut. Berbagai jenis ekspresi emosi ditunjukkan dengan musik, anak akan secara otomatis belajar tentang ekspresi musik.

5. Musik mengembangkan kreatifitas sejak dini. Anak-anak bisa menjadikan barang apapun menjadi sumber musik untuk mainan mereka. Anak-anak juga bisa belajar menyanyi, menari, bergerak aktif sesuai dengan alunan musik yang didengar.

Untuk menanamkan pendidikan karakter yang baik dibutuhkan lirik lagu yang mendidik. Lagu anak-anak atau yang dalam kesusastran bali dikenal dengan gending rare memiliki muatan pendidikan, moral, kerjasama yang baik, sekaligus nilai keagamaan dan nasionalisme. Pendidikan karakter anak usia dini melalui musik ini membuat anak memiliki sifat perangai yang riang. Anak bisa bergerak leluasa dengan iringan musik sambil menyanyikan lirik lagunya. Secara emosi terbentuk karakter yang baik pada memorinya. Media pembelajaran melalui musik dirasa lebih efektif dan efisien bisa dimengerti dan dihafal oleh anak-anak. Secara tidak langsung anak-anak akan terbawa pada situasi yang menyenangkan sehingga secara emosional dapat terkontrol dengan baik. Secara alamiah anak-anak pun terbina karakter budi pekerti yang baik dari mempelajari makna lirik lagu-lagu gending rare.
Dalam kesusastraan Bali, lagu anak anak dikenal dengan sebutan Gending Rare. Gending rare merupakan salah satu sarana komunikasi dan sosialisasi anak dengan lingkungannya. Melalui gending rare anak usia dini dapat belajar bernyanyi, bersenang-senang dan bergembira sekaligus bersosialisasi dengan kawan sebayanya. Selain itu lirik yang terdapat dalam gending rare ini juga mengandung banyak pesan moral yang dapat digunakan sebagai media penanaman karakter yang baik bagi anak usia dini . nasihat yang terkandung dalam gending rare sangat dekat dengan kehidupan sehari-hari dan dapat diaplikasikan dengan mudah.

\section{Sekar Rare / Gending Rare}

Kasusastraan Bali berarti segala hasil karya cipta sastra yang mempergunakan bahasa Bali sebagai media komunikasinya, dan memuat kehidupan masyarakat Bali secara imajinatif. Pada umumnya, kasusastraan bali telah dikomunikasikan dengan memakai huruf Bali dan huruf Latin. Para pengarang Bali diistilahkan dengan nama pengawi yang dalam istilah masa kini disejajarkan dengan istilah penyair (puisi), sastrawan (prosa), dalam jaman tradisional istilah karangan disebut karya atau damel, seperti sekar rare, sekar alit, sekar madya, sekar agung, disamping lontar bergambar atau diistilahkan denganprasi. (Antara, $2011: 2$ )

$$
\text { Layaknya }
$$

kasusastraan

pada umumnya, kasusastraan Bali ada yang diaktualisasikan dalam bentuk lisan (oralty) dan bentuk tertulis (literary). Menurut kategori 
periodisasinya, kasusastraan Bali ada yang disebut Sastra Bali Purwa dan Sastra Bali Anyar. Sastra Bali Purwa merupakan sastra Bali yang diwarisi secara tradisional dalam bentuk naskah-naskah lama. Sedangkan Sastra Bali Anyar adalah karya sastra yang diciptakan masyarakat Bali yang telah mengalami modernisasi, atau biasa disebut sastra modern. Sastra Bali sebelum dikenal adanya kertas di Bali, umumnya ditulis di atas selembar daun lontar. Karena ditulis di atas daun lontar, «buku sastra» ini disebut dengan «lontar». Memang ada bentuk tertulis lainnya, seperti prasasti, dengan menggunakan media seperti batu dan lempengan tembaga, namun tidak terdapat karya sastra Bali yang ditulis di atas bilah bambu, kulit binatang, katu, dan kulit kayu. Belakangan setelah dikenal adanya kertas, penulis karya sastra Bali menuliskan karyanya di atas kertas, bahkan sudah banyak yang diketik.
Bentuk-bentuk kasusastraan Bali sangat beragam dan mengangkat berbagai tema tertentu, berikut akan penulis bahas bentuk-bentuk kasusastraan Bali itu. Bentuk-bentuk kasusastraan Bali itu meliputi Tembang (Puisi), Gancaran (Prosa), Palawakya (Prosa Liris), dan drama. Gending rare termasuk kedalam kategori tembang (puisi). Gending Rare atau Sekar Rare, mencakup berbagai jenis lagu anak-anak yang bernuansa permainan. Jenis tembang ini umumnya memakai bahasa Bali sederhana, bersifat dinamis dan riang, sehingga dapat dilakukan dengan mudah dalam suasana bermain dan bergembira. Beberapa contoh tembang adalah Mara Bangun, Merah Putih, Meong-meong, Juru Pencar, Ongkek-ongkek ongke, Indangindang Sidi, Galang Bulan, Ucung-ucung Semanggi, Pul Sinoge dan lain-lain.

Nilai Pembentukan karakter unggul dalam Sekar Rare / Gending Rare “Mara Bangun”

\begin{tabular}{|l|l|}
\hline Sekar Rare & Terjemahan \\
\hline Mara bangun & Baru bangun \\
Luhune sampatang & Bersihkanlah kamar tidur \\
Mailehan nganteg ke natahe & Sapukanlah sampah (kotoran) yang ada \\
Laut manjus & Sekeliling sampai di halaman \\
Awake kedasin & Lalu kemudian mandi \\
Suba pada bersih & Membersihkan diri \\
Ditu cening mara masuk & Kalau sudah bersih \\
\hline
\end{tabular}


Interpretasi :

- Secara harfiah, lagu diatas adalah sebuah wejangan bagi seorang anak agar selalu menerapkan disiplin dan cinta terhadap kebersihan diri dan wilayah sekitar serta rajin menimba ilmu

- Secara filsafat, di sini hubungan antara manusia dengan Tuhan. manusia dipandang sebagai anak (cening) dan tuhan adalah orang tua semesta yang penuh cinta kasih yang memberikan wejangan suci. Ketika manusia itu sadar (bangun), bersihkanlah raga (tempat tidur) ini, tempat yang menyebabkan manusia itu lupa terhadap esensi hidup. Segala kekotoran harus dihilangkan, dari kehidupan diri dan sekitarnya. Di saat semua sudah bersih, barulah manusia itu bisa dikatakan masuk ke wilayah atapun kehidupan suci.

Nilai Pembentukan karakter Nasionalis dalam Sekar Rare / Gending Rare "Merah Putih"

\begin{tabular}{|l|l|}
\hline Sekar Rare & Terjemahan \\
\hline Merah putih benderan titiange & Merah Putih bendera Saya \\
Berkibaran di langite terang galang & Berkibar-kibar di langit yang cerah bercahaya \\
nika lambang jiwan rakyat Indonesia & Itulah perlambang dari jiwa rakyat Indonesia \\
merah berani madasar hatine suci & Berah berarti berani didasarkan pada hati yang suci \\
pusaka adi leluhur jaya sakti & $\begin{array}{l}\text { (bendera ini) merupakan Pusaka utama dari para } \\
\text { merah putih benderan tiange }\end{array}$ \\
\end{tabular}

Lagu berjudul "Merah Putih" ini diciptakan oleh almarhum Gde Dharna, Sang Pengobar Api Nasionalisme Masyarakat Bali. Lagu ini begitu populer dan melekat di kalangan masyarakat Bali, baik anak-anak, pemuda hingga orang tua. Di sekolah-sekolah di Bali, lagu ini kerap menjadi tembang wajib yang harus dinyanyikan siswa selain lagulagu perjuangan berbahasa Indonesia. Semangat nasionalisme dalam lagu "Merah Putih" bukanlah tanpa alasan. (Alm) Gde Dharna juga seorang veteran pejuang. Tahun 1946-1948. Lagu perjuangan ini ciptaan Dharna memiliki cerita khusus. Pada peristiwa "Perang Bendera" di Pelabuhan Buleleng di Singaraja pada 27 Oktober 1945. Seorang pejuang asal Banjar Liligundi Singaraja, Ketut Merta, gugur. Saat peristiwa itu, Dharna yang baru berusia 14 tahun mengalami luka di kaki. Namun, dia masih bisa membuat lencana merah putih dan menyerahkannya kepada para pejuang di depan rumahnya di Sukasada. Peristiwa itulah yang memperkuat rasa cinta Tanah Air-nya. Rasa sedih atas peristiwa gugurnya Ketut Mertha dituangkan dalam lagu "Merah Putih". 
Lirik dalam lagu ini sarat kan nilai rasa nasionalisme, kebanggaan menjadi anak Indonesia. Kecintaan akan bendera Negara, bendera merah putih. Liriknya yang mudah dinyanyikan oleh anak-anak dengan nada yang mendayu menyusup dalam kedalam sanubari anak-anak yang mendengarkan dan menyanyikannya. Melalui lagu ini diharapkan anak anak usia dini dapat memiliki rasa kecintaan dan kebanggan atas Negara dan bangsanya, Republik Indonesia.

\section{KESIMPULAN}

Usia lima tahun pertama pada masa kanak-kanak adalah masa terbentuknya kepribadian dasar individu. Kepribadian orang dewasa ditentukan oleh caracara pemecahan konflik antara sumbersumber kesenangan awal dengan tuntutan realita pada masa kanak-kanak. Untuk membentuk karakter mulia pada diri anak maka segala sesuatu disekitar anak harus mulia dan positif. Dengan demikian, penerapan nilai-nilai moral yang baik membentuk karakter anak sebaiknya dikenalkan sejak usia dini dan melibatkan lingkungan.

Salah satu cara untuk membentuk karakter anak-anak adalah dengan cara memperkenalkan lagu anak-anak yang bermuatan nilai-nilai positif dan pesan moral di dalamnya. Nilai moral yang disisipkan dalam lirik lagu anakanak ini dimaksudkan untuk mendidik perkembangan psikologi seorang anak. Menurut penelitian yang telah dikembangkan, mendidik seorang anak melalui lagu akan lebih efektif karena melalui musik akan lebih mudah diinterpretasi oleh otak anak serta akan cenderung bertahan lebih lama dalam ingatannya.

Untuk menanamkan pendidikan karakter yang baik dibutuhkan lirik lagu yang mendidik. Lagu anak-anak atau yang dalam kesusastran bali dikenal dengan gending rare memiliki muatan pendidikan, moral, kerjasama yang baik, sekaligus nilai keagamaan dan nasionalisme. Pendidikan karakter anak usia dini melalui musik ini membuat anak memiliki sifat perangai yang riang. Anak bisa bergerak leluasa dengan iringan musik sambil menyanyikan lirik lagunya. Secara emosi terbentuk karakter yang baik pada memorinya. Media pembelajaran melalui musik dirasa lebih efektif dan efisien bisa dimengerti dan dihafal oleh anak-anak. Secara tidak langsung anak-anak akan terbawa pada situasi yang menyenangkan sehingga secara emosional dapat terkontrol dengan baik. Secara alamiah anak-anak pun terbina karakter budi pekerti yang baik dari mempelajari makna lirik lagu-lagu gending rare. Contoh Gending Rare yang dijelaskan dalam tulisan ini adalah gending rare berjudul "mara bangun" dan "merah putih".

Gending rare berjudul "mara bangun" memberikan wejangan bagi seorang anak agar selalu menerapkan disiplin dan cinta terhadap kebersihan diri dan wilayah sekitar serta rajin menimba ilmu. Sedangkan Gending rare berjudul "merah putih" sarat kan nilai rasa nasionalisme, kebanggaan menjadi anak Indonesia. Kecintaan akan bendera Negara, bendera merah putih. 
DAFTAR PUSTAKA

Antara, I Gusti Putu. 2005. Sastra Bali Purwa. Singaraja: Fakultas Bahasa dan Seni Universitas Ganesha.

Antara, I Gusti Putu. 2011. Prosa Fiksi. Singaraja : Fakultas Bahasa dan Seni Universitas Ganesha.

Kemendiknas. 2010. Pembinaan

Pendidikan Karakter di Sekolah Menengah Pertama. Jakarta

Megawangi, Ratna. 2002. "Mampukah Kita Memperbaiki Moral Bangsa", Suara Pembaruan, (10 Mei 2002) . 2004. Pendidikan

Karakter: Solusi yang Tepat untuk Membangun Bangsa. Jakarta: Indonesia Heritage Foundation
.2006. "Perbaiki Moral

Bangsa Lewat Sekolah Karakter", Mitranetra, 24 Mei 2006.

Nur, H. (2013). Membangun Anak Melalui Permainan Anak Tradisional. Jurnal Pendidikan Karakter. Vol.3 (1), hal 1-8

Sholehudin, M. 2000. Konsep Dasar Pendidikan Prasekolah. Bandung: Fakultas Ilmu Pendidikan Indonesia.

Wibowo, Timothy. 2013. "Membangun Karakter Sejak Pendidikan Anak Usia Dini", diunduh dari http:// www.pendidikankarakter.com/ me mbangunkarakter-sejakpendidikan-anak-usia-dini/ pada tanggal 20 Juni 2013 